\title{
Kinetic characterization of lactate dehydrogenase in normal and malignant human breast tissues
}

\author{
Abdolhassan Talaiezadeh ${ }^{1}$, Ali Shahriari ${ }^{2}$, Mohammad Reza Tabandeh², Payam Fathizadeh ${ }^{1}$ and Siavash Mansouri ${ }^{2^{*}}$
}

\begin{abstract}
Background: Aerobic glycolysis rate is higher in breast cancer tissues than adjacent normal tissues which providethe ATP, lactate and anabolic precursors required for tumourgenesis and metastasis. Lactate dehydrogenase $(\mathrm{LDH})$ is a critical enzyme during aerobic glycolysis as it is typically responsible for the production of lactate and regeneration of $\mathrm{NAD}^{+}$, which allows for the continued functioning of glycolysis even in the absence of oxygen. LDH has been found to be highly expressed in breast tumors. Enzyme kinetic characteristics is related to environmentinvolving the enzyme, and tumor microenvironment has distinct features relative to adjacent normal tissues, thus we hypothesized that LDH should have different kinetic characteristics in breast tumors compared to normal breast tissues.
\end{abstract}

Methods: LDH was partially purifiedfrom human breast tumors and normal tissues, which were obtained directly from operating room. TheMichaelis-Menten constant $\left(K_{m}\right)$, maximum velocity $\left(V_{\max }\right)$, activation energy $\left(E_{a}\right)$ and enzyme efficiency in breast tumors and normal tissueswere determined.

Results: It was found that tumor LDH affinity in forward reaction was the same as normal LDH but $V_{\max }$ of cancerous $L D H$ was higher relative to normal $L D H$. In reverse reaction, affinity of tumor $L D H$ for lactate and $N A D^{+}$ was lower than normal LDH, also enzyme efficiency for lactate and $\mathrm{NAD}^{+}$was higher in normal samples. The $\mathrm{E}_{\mathrm{a}}$ of reverse reaction was higher in cancerous tissues.

Conclusions: It was concluded that thelow LDH affinity for lactate and $\mathrm{NAD}^{+}$is a valuable tool for preserving lactate by cancer cells. We also conclude that increasing of LDH affinity may be a valid molecular target to abolish lactate dependent tumor growth and kinetic characteristics of LDH could be a novel diagnostic parameter for human breast cancer.

Keywords: Breast cancer, Aerobic glycolysis, Lactate dehydrogenase, Enzyme kinetic

\section{Background}

Excessive growth is an important characteristic of cancer cells. One of the main distinguishing features between the normalcells and cancer cells is in their intermediary metabolism [1]. Glycolysis and oxidative phosphorylation are two major metabolism pathways for producing ATP in mammalian cells [2]. Although oxidative phosphorylation produces higher ATP from one mole of glucose when compared to glycolysis, many questions remain about the efficiency of these pathways for support of excessive growth in cancer cells. According to the basic economic law of supply and demand, oxidative phosphorylation in

\footnotetext{
* Correspondence: siavash668@yahoo.com

${ }^{2}$ Department of Biochemistry and Molecular Biology, Faculty of Veterinary

Medicine, Shahid Chamran University of Ahvaz, Ahvaz, Iran

Full list of author information is available at the end of the article
}

normal cells is more efficient than glycolysis, but this does not apply to cancer cells. Cancer cells mainly generate ATP through glycolysis even in the presence of normal oxygen pressure [3]. Conversion of glucose to lactic acid in the presence of oxygen is known as aerobic glycolysis or the Warburg effect. Increased glycolysis is mostly observed in cancer cells. This bioenergetics and metabolic feature not only permits cancer cells to survive under adverse conditions such as hypoxia, but also enables their proliferation, invasion and subsequent distant metastasis. This condition alters cellular microenvironment and makes it toxic for other cells, but has no harmful effect on cancer cells [4]. High glycolysis results in environmental acidosis that facilitates invasion of cancer cells through destruction of adjacent 
normal populations, degradation of the extracellular matrix and promotion of angiogenesis [5].

The inhibition of Warburg effect may be used to attenuate the growth advantages of cancer cells; however, its precise molecular mechanisms are not completely understood. Different mechanisms have been described for glycolysis alteration in cancer cells [6,7]. One possiblereason for this bioenergetics alteration is the release of various enzyme activators or inhibitors, which can change the kinetic properties of enzymes involved in glucose metabolism. Environmental parameters like $\mathrm{pH}$, temperature, or nutrient availability can influence enzyme activities and characteristics via transcriptional, posttranscriptional, posttranslational, or allosteric regulations. Slight attention has been paid to alteration of enzyme kinetic in tumor environment, which can change intrinsic characteristics of enzymes and metabolic pathways.

$\mathrm{LDH}$ is the final enzyme in glycolysis pathway that catalyzes interconversion of pyruvate and lactate and it also regenerates $\mathrm{NAD}^{+}$, which isnecessary for continued high glycolysis rate in cancer cells. The gene expression and activity of LDH (in pyruvate reducing direction) is higher in breast cancer cells relative to adjacent normal cells. Also, upregulation of the LDH-A in clinical tumors is often associated with disease progression and poor prognosis [8-12]. Interestingly, clinical evaluation of LDH-B could be a predictive marker of response for patients with breast cancer receiving neoadjuvant chemotherapy [13]. Given the findings, it is concluded that LDH is animportant effector of glucose metabolism in cancer cells and can affect tumorigenesis and metastasis. Possible changes in kinetic parameters of LDH with attention to different tumor microenvironmentshave not been studied in cancer tissue. The aim of the current study was to compare the kinetic properties of lactate dehydrogenase between breast cancer and normal mammary tissue.

\section{Material and methods}

\section{Clinical sample collection}

Seventeen human breast tumor samples were obtained from Apadana Hospital during the surgery. Normal tissues away from the tumor were included as controls. Two independent expert pathologists from the pathology laboratory of Apadana hospital carried out the pathological tumor and control tissue examination. The clinical and histological characteristics of breast cancer patients are shown in Table 1 . Samples were immediately preserved in liquid nitrogen, transported to the laboratory, and stored at $-80^{\circ} \mathrm{C}$. The study was approved by the ethics committee from Jundishapour Medical University of Ahvaz and conducted according to the Guide for Human study by the National Academy of Sciences (National Institutes of Health), and informed
Table 1 Clinico-pathological characteristics of the examined breast cancer patients

\begin{tabular}{lll}
\hline Clinical characteristics & Grade & \% of patients \\
\hline Age (years) & $<40$ & 35.29 \\
\cline { 2 - 3 } & $40-49$ & 23.52 \\
\cline { 2 - 3 } & $\mathbf{5 0 - 5 9}$ & 35.29 \\
\cline { 2 - 3 } Histopathological grade & 1 grade & 5.8 \\
\cline { 2 - 3 } & 2 grade & 14.28 \\
\cline { 2 - 3 } & 3 grade & 57.14 \\
\hline Cellular characteristics & Ductal carcinoma invasive & 86.66 \\
\cline { 2 - 3 } & Ductal carcinoma in situ & 13.33 \\
\hline Tumor size & $2.1-3.0$ & 13.33 \\
\cline { 2 - 3 } & $>3.1$ & 86.66 \\
\hline Auxillary lymph nodes status & Metastasis negative & 33.33 \\
\cline { 2 - 3 } & Metastasis positive & 66.66 \\
\hline
\end{tabular}

consent was obtained from all patients involved in this study.

\section{Sample preparation and LDH partial purification}

Frozen tumors and normal tissues were homogenized $(1: 5 \mathrm{w}: \mathrm{v})$ in ice cold homogenization buffer (20 mMTris- $\mathrm{HCl}, \mathrm{pH}$ 8.0, $10 \mathrm{mM}$ 2-mercaptoethanol, 10\% v:v glycerol, 2 mM EDTA, $2 \mathrm{mM}$ EGTA, and $20 \mathrm{mM} \beta$ glycerophosphate) and a few crystals of phenylmethylsulphonyl fluoride (PMSF) were added at the time of homogenization. Samples were homogenized using a Miccra homogenizer (Miccra, Germany), centrifuged for $30 \mathrm{~min}$ at $13,500 \mathrm{~g}$ at $4^{\circ} \mathrm{C}$ and the supernatant was decanted and held on ice until use. Low molecular weight metabolites and ions were removed from the supernatant by Sephadex G25 columns $(1 \times 5 \mathrm{~cm})$ (Sigma, Germany) that had been equilibrated in homogenizing buffer [14].

LDH partial purification began with the preparation of a DEAE-Sephasex column $(1.5 \times 10 \mathrm{~cm})$ that was equilibrated in assay buffer $(20 \mathrm{mM}$ Tris- $\mathrm{HCl}, \mathrm{pH}$ 8). Following equilibration, approximately $1.5 \mathrm{~mL}$ of crude extract was placed on top of the column. The column was then washed with $30 \mathrm{~mL}$ of assay buffer to remove any unbound proteins like LDH.

Additional experiments required a much pure LDH sample, and therefore the top peak activity fractions from the DEAE-Sephadex column were combined and chromatographed on a Blue Sepharose CL-6B column $(1.5 \times 10 \mathrm{~cm})$ pre-equilibrated in homogenization buffer. Following equilibration, the column was then washed with $50 \mathrm{~mL}$ of homogenization buffer to remove any unbound proteins. A linear salt gradient of $0-2 \mathrm{M} \mathrm{KCl}$ was then applied to the column for the elution of $\mathrm{LDH}$. Top activity fractions were then pooled and held at $4^{\circ} \mathrm{C}$ until use. This 
Table 2 Purification scheme for LDH in cancerous breast samples

\begin{tabular}{llllll}
\hline Purification step & Total protein $(\mathbf{m g})$ & Total activity $(\mathbf{U})$ & Specific activity $(\mathbf{U} / \mathbf{m g})$ & Fold purification & \% yield \\
\hline Supernatant & 15 & 5.1 & 0.3 & - & - \\
\hline DEAE-Sephadex & 3.6 & 2.7 & 0.7 & 2.3 & 52 \\
\hline Blue Sepharose CL-6B & 0.2 & 0.73 & 3.6 & 12 & 14 \\
\hline
\end{tabular}

sample was used for subsequent kinetic characterization of LDH [14].

\section{Enzyme assay and kinetic parameters}

LDH activity was measured in the presence of pyruvate with NADH as substrate for forward reaction and lactate with $\mathrm{NAD}^{+}$as substrate for reverse reaction. The lowest saturating concentration of each substrate, which simultaneously showed maximum velocity, constant rate of product formation and linear regressions of activities for serial dilutions of enzyme, was assigned as optimum substrate concentration.

Reactions were initiated by adding $10 \mu \mathrm{l}$ of purified enzyme to a $200 \mu \mathrm{l}$ total reaction volume by using $20 \mathrm{mM}$ Tris- $\mathrm{HCl}$ buffer $\mathrm{pH} 8$, in the microplate well. Activity was monitored at $340 \mathrm{~nm}$ for checking the conversion of $\mathrm{NADH}$ to $\mathrm{NAD}^{+}$(or vice versa) by using a Biotech Powerwave X2s microplate reader (Biotech, USA) and Gen5 software version 2.0 (USA) (kinetic mode, reading interval = $39 \mathrm{~s}$ ). The enzyme activity was expressed as nmoles of pyruvate or lactate formed/min for reverse and forward reactions, respectively.

Data were analyzed using microplate analysis (MPA) and kinetics programs $3.51[15,16]$. Kinetics 3.51 computer program fitted data through a nonlinear least squares regression for determination of $\mathrm{K}_{\mathrm{m}}$ (substrate concentration giving half-maximal activity; Michaelis-Menten constant) and $\mathrm{V}_{\max }$ (maximum velocity) values.

The $K_{m}$ pyruvate was determined at $0.5 \mathrm{mM} \mathrm{NADH}$ and pyruvate concentrations ranged from $0.05 \mathrm{mM}$ to $2.15 \mathrm{mM}$. The $\mathrm{K}_{\mathrm{m}} \mathrm{NADH}$ was determined at $1.5 \mathrm{mM}$ pyruvate and NADH concentrations ranged from 0.1 to $0.95 \mathrm{mM}$. In normal tissues, the $\mathrm{K}_{\mathrm{m}}$ lactate was determined at $3 \mathrm{mM} \mathrm{NAD}^{+}$and lactate concentrations ranged from 5-115 mM, while the $\mathrm{K}_{\mathrm{m}} \mathrm{NAD}^{+}$was determined at $90 \mathrm{mM}$ lactate and $\mathrm{NAD}^{+}$concentrations ranged from 0.25 to $8.5 \mathrm{mM}$. In tumor samples, the $\mathrm{K}_{\mathrm{m}}$ lactate was determined at $5 \mathrm{mM} \mathrm{NAD}^{+}$and lactate concentrations ranged from 10-325 $\mathrm{mM}$ while the $\mathrm{Km} \mathrm{NAD}^{+}$was determined at $250 \mathrm{mM}$ lactate and $\mathrm{NAD}^{+}$concentrations ranged from 0.5 to $9.5 \mathrm{mM}$. All assayswererun in $0.2 \mathrm{M}$ Tris- $\mathrm{HCl}$ buffer, $\mathrm{pH}$ 8.0. All reactions were done in triplicate. The $\mathrm{K}_{\mathrm{m}}$ and $\mathrm{V}_{\max }$ were calculated from the mean of three separate series of determinations. Total protein content was measured using Bradford method and bovine serum albumin as standard.

Given the possible existence of endogenous NADH to $\mathrm{NAD}^{+}$interconvesrion (i.e. NADH oxidation by complex I activity) in partial purified samples, the NADH to $\mathrm{NAD}^{+}$interconversion was surveyed in each sample to eliminate the possible existence of its effect. This interconversion was determined by adding the NADH (0.5-1 mM) or $\mathrm{NAD}^{+}(3-5 \mathrm{mM})$ in Blue Sepharose purified samples and monitoring the change in absorbance at $340 \mathrm{~nm}$.

\section{Calculation of activation energy}

Maximal LDH activity was determined at $5^{\circ} \mathrm{C}$ increments starting from $18^{\circ} \mathrm{C}$ and ending at $42^{\circ} \mathrm{C}$. The reaction temperature was set by using incubator of Biotech Powerwave X2s microplate reader. Substrates concentrations were as follow: $1.5 \mathrm{mM}$ pyruvate and $0.5 \mathrm{mM} \mathrm{NADH}$ in forward reaction, $90 \mathrm{mM}$ lactate and $3 \mathrm{mM} \mathrm{NAD}^{+}$in reverse reaction for normal tissues, $250 \mathrm{mM}$ lactate and $5 \mathrm{mM} \mathrm{NAD}^{+}$in reverse reaction for tumor tissues. Arrhenius plots were constructed from these experiments and the $E_{a}$ was calculated.

\section{Calculation of enzyme efficiency}

To determine enzyme efficiency the $\mathrm{V}_{\text {max }} / \mathrm{K}_{\mathrm{m}}$ lactate and $\mathrm{V}_{\text {max }} / \mathrm{K}_{\mathrm{m}} \mathrm{NAD}^{+}$ratio were calculated for tumor and normal samples.

\section{Statistical analysis}

Data were expressed as mean \pm SEM from independent determinations on separate preparations of enzyme. Data were analyzed using Student's $t$-test. The level of significance for all tests was set at $p<0.05$.

Table 3 Purification scheme for LDH in normal breast samples

\begin{tabular}{|c|c|c|c|c|c|}
\hline Purification step & Total protein (mg) & Total activity (U) & Specific activity (U/mg) & Fold purification & $\%$ yield \\
\hline Supernatant & 8.5 & 2.4 & 0.28 & - & - \\
\hline DEAE-Sephadex & 1.9 & 1.35 & 0.71 & 2.5 & 56 \\
\hline Blue Sepharose CL-6B & 0.18 & 0.42 & 2.3 & 8.2 & 17 \\
\hline
\end{tabular}




\section{Results}

\section{LDH partial purification}

The purification procedure employed was proven to be efficient; a typical purification experiment is summarized in Tables 2 and 3. DEAE-G50 Sephadex chromatography resolved one peak activity of $\mathrm{LDH}$ from tumor and normal breast samples and Blue Sepharose chromatography determined one peak activity of LDH from top fractions of DEAE-G50 chromatography from both the tumor and normal samples. Peak activity of LDH was consistently eluted in Blue Sepharose at $0.5-1.3 \mathrm{M} \mathrm{KCl}$ from both tumor and normal breast specimens. The elution patterns of LDH showed no significant difference between tumor and normal breast tissues (Figure 1).

\section{Optimization of experimental conditions}

Optimum assay conditions for LDH in forward reaction were $1.5 \mathrm{mM}$ pyruvate and $0.5 \mathrm{mM} \mathrm{NADH}$ in both tumors and normal tissues. In the reverse reaction, optimal conditions were different in normal and tumor samples. Optimum conditions in normal samples were $90 \mathrm{mM}$ lactate and $3 \mathrm{mM} \mathrm{NAD}^{+}$while in tumor samples theywere $250 \mathrm{mM}$ lactate and $5 \mathrm{mM} \mathrm{NAD}^{+}$. It should be noted that there is no NADH to $\mathrm{NAD}^{+}$interconversion activity (or vice versa) in partially purified samples.

\section{Kinetic properties of LDH in forward reaction}

The maximal activity of cancerous-LDH (C-LDH) for lactate formation $(4034 \pm 348 \mathrm{mU} / \mathrm{mg}$ protein for pyruvate and $2788 \pm 111 \mathrm{mU} / \mathrm{mg}$ protein for $\mathrm{NADH}$ ) was higher than the values in normal tissues (N-LDH) $(1747 \pm 68 \mathrm{mU} / \mathrm{mg}$ protein for pyruvate and1370 \pm $52 \mathrm{mU} / \mathrm{mg}$ protein for $\mathrm{NADH}$ ) (Table 4). The enzyme in forward reaction in both tissues displayed sigmoidal kinetics with respect to pyruvate and NADH (Figures 2
Table 4 Kinetic parameters of LDH in forward reaction from breast tumors $(n=17)$ and normal tissues $(n=17)$

\begin{tabular}{lll}
\hline & Tumor & Normal \\
\hline$S_{0.5}$ pyruvate $(\mathrm{mM})$ & $0.78 \pm 0.07$ & $0.63 \pm 0.03$ \\
\hline$S_{0.5} \mathrm{NADH}(\mathrm{mM})$ & $0.3 \pm 0.01$ & $0.33 \pm 0.01$ \\
\hline$V_{\max }$ pyruvate $(\mathrm{mU} / \mathrm{mg}$ protein) & $4034 \pm 348^{*}$ & $1747 \pm 68$ \\
\hline$V_{\max } \mathrm{NADH}(\mathrm{mU} / \mathrm{mg}$ protein) & $2788 \pm 111^{*}$ & $1370 \pm 52$ \\
\hline$E_{a}(\mathrm{kcal} / \mathrm{mol})$ & $51 \pm 4.1$ & $41 \pm 5.6$
\end{tabular}

Assays were conducted at $25^{\circ} \mathrm{C}$ and data are presented as means \pm SEM, $n=3$ independent determinations on each of 17 tumor and normal samples. *Significant difference in each row at $\mathrm{p}<0.05$.

and 3). Hill coefficients for pyruvate and NADH in tumors were $1.36 \pm 0.12$ and $2.8 \pm 0.28$, and in normal samples were $1.36 \pm 0.07$ and $2.5 \pm 0.19$ respectively. However, the $S_{0.5}$ of pyruvate $(0.78 \pm 0.12 \mathrm{mM}$ for tumor and $0.63 \pm 0.04 \mathrm{mM}$ for normal) and NADH $(0.3 \pm 0.01 \mathrm{mM}$ for tumor and $0.33 \pm 0.01 \mathrm{mM}$ for normal) were not significantly different between normal and cancerous tissues (Table 4).

\section{Kinetic properties of LDH in reverse reaction}

The maximal activity of $\mathrm{LDH}$ with respect to lactate $(630 \pm 4.9 \mathrm{mU} / \mathrm{mg}$ protein for tumor and $602 \pm 2.2 \mathrm{mU} / \mathrm{mg}$ protein for normal) and $\mathrm{NAD}^{+}(1282 \pm 71.24 \mathrm{mU} / \mathrm{mg}$ protein for tumor and $1237 \pm 21.2 \mathrm{mU} / \mathrm{mg}$ protein for normal) were not significantly different between normal and cancerous tissues (Table 5).

The $\mathrm{K}_{\mathrm{m}}$ lactate of $\mathrm{N}$-LDH $(10.73 \pm 0.54 \mathrm{mM})$ was significantly lower than that of C-LDH (21.78 \pm $1.07 \mathrm{mM})(\mathrm{p}<0.05)($ Table 4$)$. The $\mathrm{K}_{\mathrm{m}} \mathrm{NAD}^{+}$was significantly lower in normal tissues $(0.5 \pm 0.06 \mathrm{mM})$ than that in tumor tissues $(0.99 \pm 0.2 \mathrm{mM})(\mathrm{p}<0.05)$ (Figures 4 and 5).

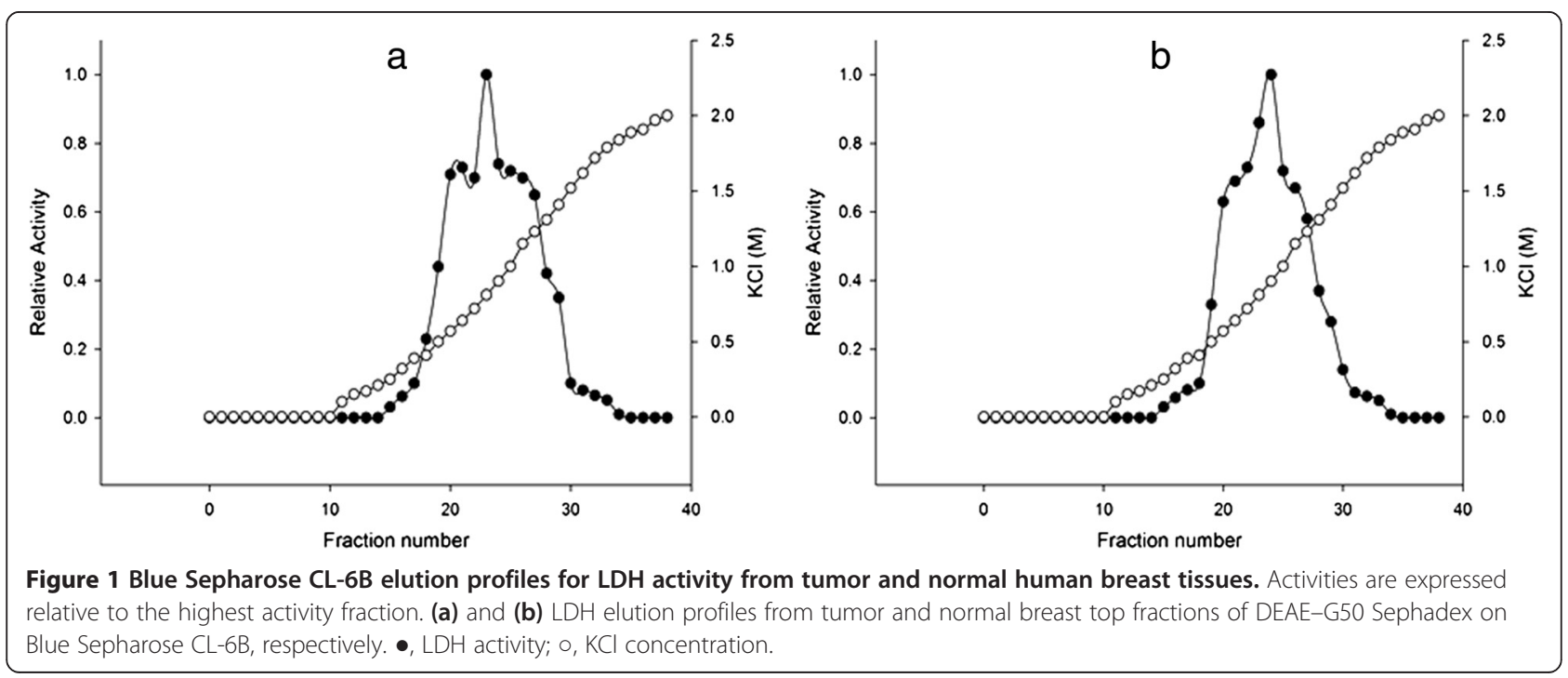



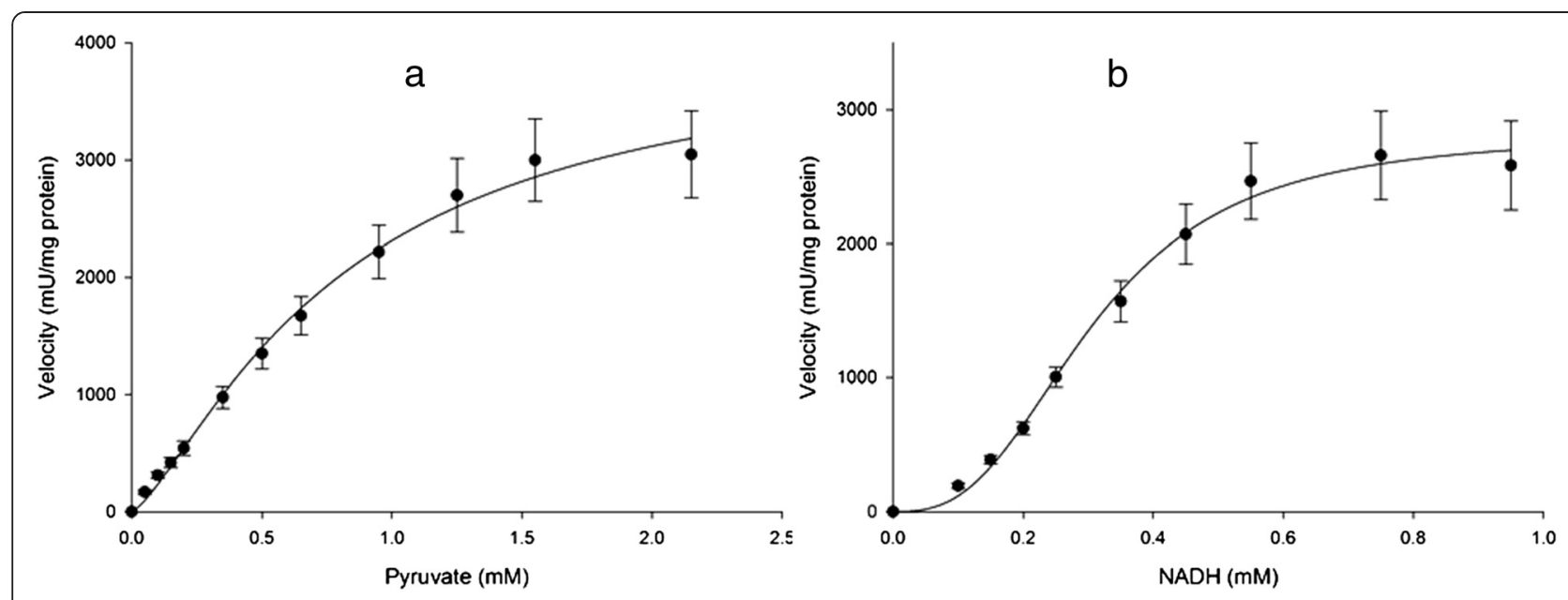

Figure 2 Initial velocity (vi) versus substrate concentration of (a) Pyruvate: 0.05-2.15 mM and (b) NADH: 0.1-0.95 mM for LDH in partial purified of breast cancer samples $(\mathbf{n}=\mathbf{1 7})$ in forward reaction. Data are presented as means $\pm S E M, n=3$ independent determinations on separate enzyme samples.

\section{Effect of temperature on LDH activity}

$E_{a}$ values of C-LDHL and $\mathrm{N}-\mathrm{LDH}$ are shown in Table 4 and 5 . The $\mathrm{E}_{\mathrm{a}}$ in forward reaction was not significantly different between thetwo tissues $(51 \pm 4.1$ $\mathrm{Kcal} / \mathrm{mol}$ for tumor and $41 \pm 5.6 \mathrm{Kcal} / \mathrm{mol}$ for normal tissue), while the $\mathrm{E}_{\mathrm{a}}$ in reverse reaction was significantly higher in cancerous tissues $(39.12 \pm 4.6 \mathrm{Kcal} / \mathrm{mol}) \mathrm{com}$ pared to that in normal tissues $(16.78 \pm 1.7 \mathrm{Kcal} / \mathrm{mol})$ $(\mathrm{p}<0.05)$.

\section{Enzyme efficiency}

Enzyme efficiency related to lactate in normal tissues was two-fold higher than tumor samples $(56.1 \pm 2.4$ and $28.92 \pm 1.3 \mathrm{mU} / \mathrm{mg} / \mathrm{mM}$, respectively). In the case of
$\mathrm{NAD}^{+}$, enzyme efficiency in normal tissues was about two-fold higher than tumor samples $(2474 \pm 8.1$ and $1294.94 \pm 6.7 \mathrm{mU} / \mathrm{mg} / \mathrm{mM}$, respectively) (Table 6).

\section{Discussion}

Glycolysis pathway has a different pattern in cancer when compared to normal cells because expression, structure and activity of some enzymes (e.g. pyruvate kinase) and some important master regulators (e.g. HIF-1, myc) are diverse $[17,18]$. The knowledge of glycolysis multiplicity is vital to comprehend the nature of the cancer cells in order to obliterate them because the best way to destroy an army is to identify all the parts of it and point out its weaker part as the Achilles' heel.
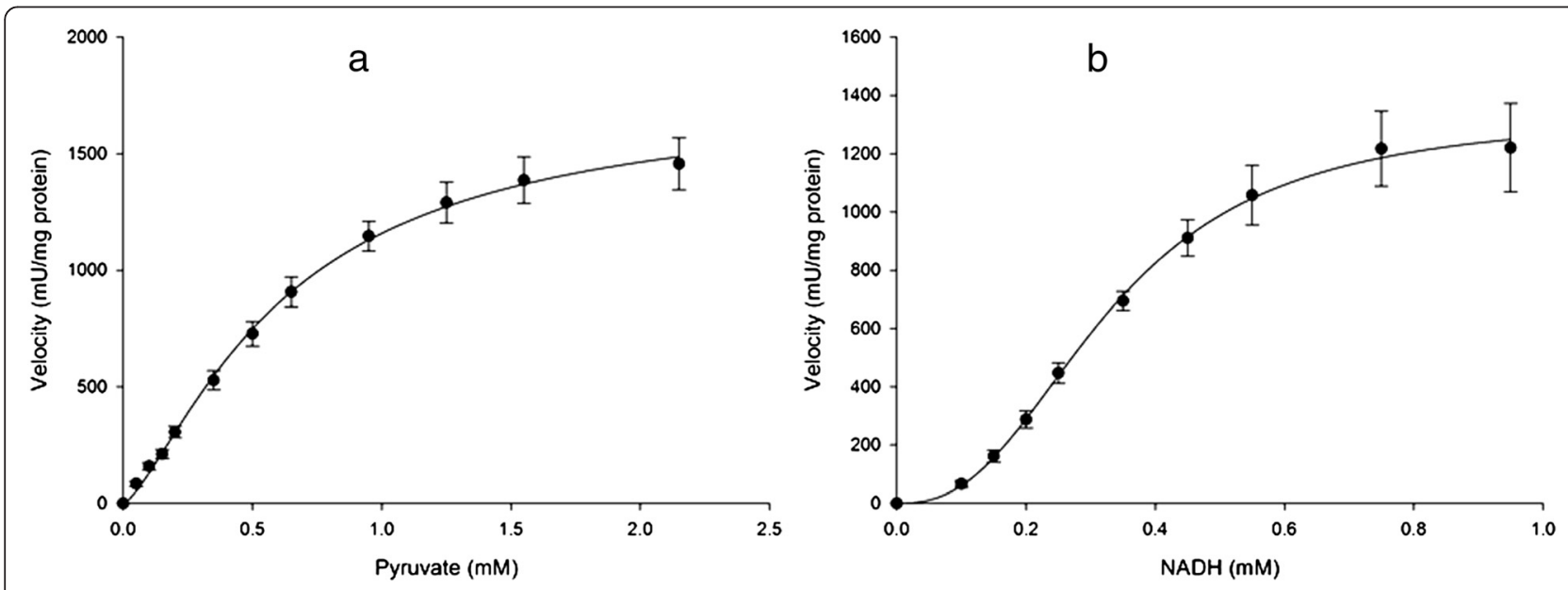

Figure 3 Initial velocity (vi) versus substrate concentration of (a) Pyruvate: 0.05-2.15 mM and (b) NADH: 0.1-0.95 mM for LDH in partial purified breast normal tissues $(\mathbf{n}=\mathbf{1 7})$ in forward reaction. Data are presented as means $\pm S E M, n=3$ independent determinations on separate enzyme samples. 
Table 5 Kinetic parameters of LDH in reverse reaction from breast tumors $(n=17)$ and normal tissues $(n=17)$

\begin{tabular}{lll}
\hline & Tumor & Normal \\
\hline $\mathrm{K}_{\mathrm{m}}$ lactate $(\mathrm{mM})$ & $21.78 \pm 1.07^{*}$ & $10.73 \pm 0.54$ \\
\hline $\mathrm{K}_{\mathrm{m}} \mathrm{NAD}^{+}(\mathrm{mM})$ & $0.99 \pm 0.05^{*}$ & $0.50 \pm 0.06$ \\
\hline $\mathrm{V}_{\text {max }}$ lactate $(\mathrm{mU} / \mathrm{mg}$ protein) & $630 \pm 4.9^{*}$ & $602.2 \pm 2.2$ \\
\hline $\mathrm{V}_{\max } \mathrm{NAD}(\mathrm{mU} / \mathrm{mg}$ protein) & $1282 \pm 71.24^{*}$ & $1237 \pm 21.2$ \\
\hline $\mathrm{E}_{\mathrm{a}}(\mathrm{kcal} / \mathrm{mol})$ & $39.12 \pm 4.6^{*}$ & $16.78 \pm 1.7$ \\
\hline
\end{tabular}

Assays were conducted at $25^{\circ} \mathrm{C}$ and data are presented as means $\pm \mathrm{SEM}, \mathrm{n}=3$ independent determinations on each of 17 tumor and normal samples.

${ }^{*}$ Significant difference in each row at $\mathrm{p}<0.05$.

It has been shown that the kinetic parameters of each enzyme in tissue are dependent on their environment. A few studies have been done which provide sufficient evidence of the alterations of kinetic properties of glycolytic enzymes in cancer cells. LDH is a key enzyme of aerobic glycolysis and attention has been paid to its kinetic parameters in cancer cell lines in recent years $[19,20]$. Those studies have come across an important problem; the tumor microenvironment has very heterogeneous oxygen pressure, $\mathrm{pH}$ and other metabolites [21] whereas the nature and importanceof the tumor microenvironment has been masked owing to the use of tissue culture conditions in which $\mathrm{pH}$ is normal without any fluctuation, also oxygen and nutrients are always in excess. This study was undertaken to compare the kinetic parameters of LDH in cancerous and normal tissues, with focus on the fact that enzyme kinetic parameters are dependent on their environment-involved enzyme. Our current study has shown the C-LDH in forward reaction has higher $\mathrm{V}_{\max }$ compared to Normal N-LDH but the $\mathrm{S}_{0.5}$ of $\mathrm{LDH}$ between two tissues was not different. Elevation of C-LDH $V_{\max }$, with respect to its constant $S_{0.5}$, can be due to increasein the total concentration of enzyme in tumor tissue. Higher $\mathrm{V}_{\max }$ of C-LDH with respect to pyruvate and $\mathrm{NADH}$ showed significantly increased lactate and $\mathrm{NAD}^{+}$production and increased pyruvate and NADH consumption. Three lines of evidence can explain our findings. Firstly, cancer cells require further levels of $\mathrm{NAD}^{+}$for a continuing high glycolysis rate [4] and high activity of LDH in forward reaction supplies this requirement. Secondly, a high glycolysis rate in tumor cells increases the level of NADH. The increasing of NADH stimulates release of membrane bound LDH (A4) and more conversion of NADH to $\mathrm{NAD}^{+}$with concomitant consumption of pyruvate A4 isoenzyme activity that catalyzes forward reaction will be increased in a metabolic environment containing low oxygen supply and ample pyruvate [22]. The two features exist in tumors, depressed supply of oxygen occurs in tumor microenvironment because blood vessels in tumors are often highly abnormal [23,24], also high glycolysis rate in cancer cells produces higher pyruvate level [25]. Our observations are consistent with the above clarification; the activity of $\mathrm{LDH}$ in forward reaction is higher in tumors than normal tissues. In addition, reducing the level of pyruvate by LDH in tumor tissues may assist cancer cells to maintain excessive growth and proliferation and may inhibit cancer cell death. To confirm this hypothesis Thangaraju et al. has shown that pyruvate prevents cell growth and proliferation by inhibition of histone deacetylase activity [26]. High LDH activity in forward reaction by altering pyruvate could eliminate the effect of pyruvate on cancer cell growth.

$\mathrm{LDH}$ in reverse reaction converts lactate to pyruvate with concomitant generation of $\mathrm{NAD}^{+}$from NADH. Our results demonstrated that C-LDH had higher $\mathrm{K}_{\mathrm{m}}$ for both lactate and $\mathrm{NAD}^{+}$when compared with $\mathrm{N}-\mathrm{LDH}$. Contrary to our data, Debari et al. and Pizzuto et al. have shown that $\mathrm{K}_{\mathrm{m}}$ lactate and $\mathrm{K}_{\mathrm{m}} \mathrm{NAD}^{+}$were not different in PC3 and HEP G2 cell lines in relation to normal cells. The difference between our data and that reported by other researchers may be related to the culture a

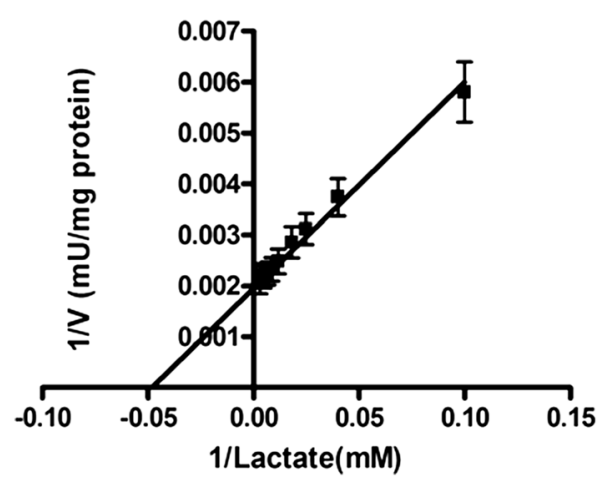

b

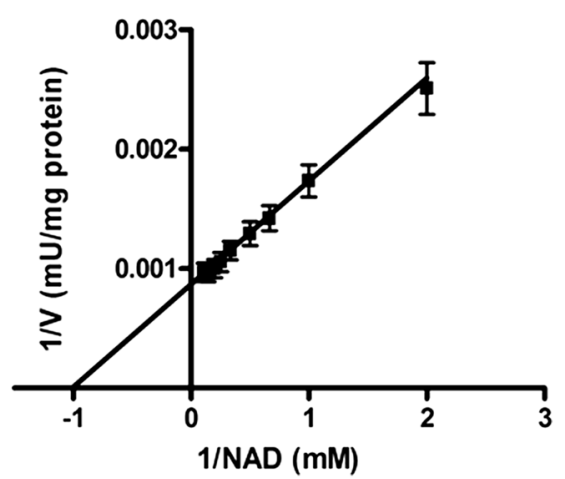

Figure 4 Lineweaver-Burk plots of LDH in partial purified breast cancer tissues $(n=17)$ for (a) Lactate: $10-325$ mM and (b) NAD 0.5-9.5 $\mathrm{mM}$ in reverse reaction. Data are presented as means $\pm S E M, n=3$ independent determinations on separate enzyme samples. 

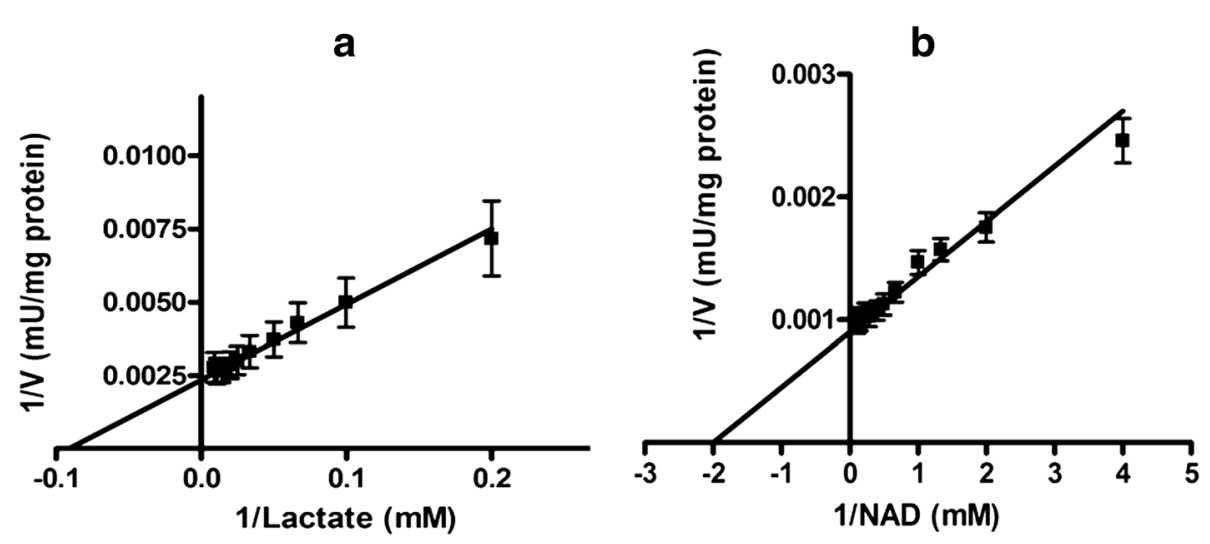

Figure 5 Lineweaver-Burk plots of LDH in partial purified breast normal tissues $(n=17)$ for (a) Lactate: 5-110 mM and (b) NAD': 0.25-8.5 mM in reverse reactions. Data are presented as means $\pm S E M, n=3$ independent determinations on separate enzyme samples.

environment that is a precise fit for cancer cell growth and proliferation, whereas the microenvironment of tumor tissue has various limitations that stimulates cancer cells to change their metabolism for persistent living and proliferation [21,27].

Higher $\mathrm{K}_{\mathrm{m}}$ lactate and $\mathrm{NAD}^{+}$means the C-LDH has a lower affinity for lactate and $\mathrm{NAD}^{+}$to catalyze reverse reaction in tumor tissues, in other words, cancer cells resist converting lactate to pyruvate. This could be related to the key role of lactate in tumors. It has been shown that lactate contributes to the immune escape of cancer cells by inhibition of monocytes and dendritic cells differentiation and also by reduction of cytokine release from dendritic and cytotoxic $\mathrm{T}$ cells. In addition, the extrusion of high amount of lactate produced by aerobic glycolysis to the extracellular space could inhibit the lactate secretion from immune cells due to change in intra- to extracellular lactate balance. These changes suppress cellular immunity in tumor tissue [28]. Another possibility to explain our finding is the role of lactate in tumor metastasis and angiogenesis. Lactate indirectly enhances endothelial cell migration and angiogenesis by stimulating vascular endothelial growth factor (VEGF) production [29]. Lactate also increases the acidity of extracellular $\mathrm{pH}$, a condition that stimulates invasion and metastasis of cancer cells [30]. The above mentioned traits of lactate make it very valuable for cancer cells, because

Table 6 The enzyme efficiency, represented as $V_{\text {max }} / K_{m}$ for LDH in partial purified tumor and normal breast tissues

\begin{tabular}{lll}
\hline & Tumor & Normal \\
\hline$V_{\text {max }} / K_{m}$ with lactate $(\mathrm{mU} / \mathrm{mg} / \mathrm{mM})$ & $28.92 \pm 1.3^{*}$ & $56.1 \pm 2.4$ \\
\hline$V_{\text {max }} / \mathrm{K}_{\mathrm{m}}$ with $\mathrm{NAD}^{+}(\mathrm{mU} / \mathrm{mg} / \mathrm{mM})$ & $1294.94 \pm 6.7^{*}$ & $2474 \pm 8.1$ \\
\hline Assays
\end{tabular}

Assays were conducted at $25^{\circ} \mathrm{C}$ and data are presented as means $\pm S E M, n=3$ independent determinations on each of 17 tumor and normal samples.

*Significant difference in each row at $p<0.05$. according to Darwinian process, any traits that confer selective advantages to one population arepreserved by the population, therefore cancer cells should protect lactate because of its benefits in tumorigenesis. Low LDH affinity for lactate is one way of preserving lactate that is observedin the current study.

In addition, higher $\mathrm{K}_{\mathrm{m}}$ lactate in C-LDH shows the $\mathrm{C}-\mathrm{LDH}$ is less inhibited by high concentration of lactate and higher lactate levels could be tolerated. This feature of C-LDH may reflect one of the traits of the tumor microenvironment, which is a higher lactate level. Lactate level is significantly higher in tumors with metastatic spread in comparison to malignancies in patient without metastases $[31,32]$. Given the meaningful correlation between lactate concentrations in tumors with metastatic incidence, it can be concluded that the kinetic parameters of $\mathrm{LDH}$, with respect to lactate, should be different in patients with metastases as one of the most effective factors on an enzyme kinetic is the characteristic of the environment that involves the enzyme.

The lower affinity of LDH for reverse reaction in tumors compared with normal tissues was emphasized by calculating the C-LDH and N-LDH efficiencies [33]. Our results showed that LDH efficiency was higher for lactate and $\mathrm{NAD}^{+}$in normal tissues compared to tumors, which means that normal cells have more affinity to lactate in relation to tumor tissue which is consistent with the above mentioned explanations.

Our results demonstrated that $E_{a}$ of reverse reaction was higher in tumors than that in normal tissues. This finding provides novel thermodynamic evidence about the inappropriate application of reverse reaction in tumor cells. In general, the higher values of $K_{m}$ and $E_{a}$ and lower enzyme efficiency for tumor LDH in reverse reaction showed cancer cells resist the conversion of lactate to pyruvate. It is important to note that substrate preference for reverse reaction by C-LDH and N-LDH 
may be due to their posttranslational modification during the tumorigenesis. Further investigation is needed to detect the posttranslational modification of LDH in cancer tissue and its effect on LDH structure and kinetic parameters.

\section{Conclusions}

The results demonstrated that C-LDH has high affinity to produce lactate in forward reaction while it has low tendency to produce pyruvate in reverse reaction. Most studies have suggested inhibiting LDH activity in forward reaction [34] as one possible targeted therapy because the activity and expression of $\mathrm{LDH}$ in forward reaction is higher in cancer cells than normal cells. The current study showed for the first time that there is another possible approach to confront LDH effectiveness in cancer cells: if the affinity of $\mathrm{LDH}$ for lactate and $\mathrm{NAD}^{+}$can be increased, lactate is converted to pyruvate at higher rate and lactate dependent tumor growth and proliferation can be abolished. Further investigation is needed to confirm this hypothesis. In addition, the correlation between the kinetic parameters of LDH and the incidence of metastasis should be surveyed in more numbers of breast cancer patients. Finally, various enzymes kinetic parameters of different cancer cell lines should be investigated in culture conditions in which both oxygen and nutrients are restricted, similar to tumor microenvironment.

\section{Abbreviations \\ ATP: Adenosine three phosphate; LDH: Lactate dehydrogenase; NAD ${ }^{+}$: Oxidized form of nicotinamide adenine dinucleotide; NADH: Reduced form of nicotinamide adenine dinucleotide; EDTA: Ethylene diamine tetra acetic acid; EGTA: Ethylene glycol-bis(2-aminoethylether)-N,N,N',N'- tetra cetic acid; PMSF: Phenyl methyl sulphonyl fluoride; $\mathrm{K}_{\mathrm{m}}$ : Michaelis-Menten constant; $V_{\text {max: }}$ Maximum velocity; $E_{a}$ : Activation energy; HIF: Hypoxia inducible factor; VEGF: Vascular endothelial growth factor.}

\section{Competing interests}

The authors declare that they have no competing interests.

\begin{abstract}
Authors' contributions
AT was responsible for project planning, took samples and supported the research. AS conceived the study and supervised the overall experimental design, execution and helped to revise the manuscript. MRT participated in the design of study, reviewed the entire manuscript and edited the manuscript. PF was responsible for pathological assessment of the tissue samples. SM carried out all of the experiments, aided in intellectual design of the experiments, drafted and revised the manuscript. All authors read and approved the final manuscript.
\end{abstract}

\section{Acknowledgements \\ The authors thank Dr. Steve Brooks for his critical advice about kinetic analysis of data and the chief of Apadana Hospital for his sincere cooperation in this project. This work was funded by grants from Cancer, Petroleum and Environmental Pollutants Research Center, Ahvaz Jundishapur University of Medical Sciences and Shahid Chamran University of Ahvaz Research Council (Grant No: 636410, 1392.4.6).}

\section{Author details}

${ }^{1}$ Cancer, Petroleum and Environmental Pollutants Research Center, Ahvaz Jundishapur University of Medical Sciences, Ahvaz, Iran. ${ }^{2}$ Department of Biochemistry and Molecular Biology, Faculty of Veterinary Medicine, Shahid Chamran University of Ahvaz, Ahvaz, Iran.
Received: 10 June 2014 Accepted: 26 January 2015

Published online: 15 February 2015

\section{References}

1. Hanahan D, Weinberg RA. Hallmarks of cancer: the next generation. Cell. 2011;144:646-74

2. Murray RK, Bender DA, Botham KM, Kennelly PJ, Rodwell WW, Anthony Weil P. Harper's illustrated biochemistry. 27th ed. USA: Lange Medical Books/MacGraw-Hill Companies; 2006.

3. Warburg O. On the origin of cancer cells. Science. 1956;123:309-14.

4. Gatenby RA, Gillies RJ. Why do cancers have high aerobic glycolysis? Nat Rev Cancer. 2004;4:891-9.

5. Rofstad EK, Mathiesen B, Kindem K, Galappathi K. Acidic extracellular pH promotes experimental metastasis of human melanoma cells in athymic nude mice. Cancer Res. 2006;66:6699-707.

6. Dakubo GD. Mitochondria genetic and cancer. 1st ed. England: Springer; 2010.

7. Levine AJ, Puzio-Kuter AM. The control of the metabolic switch in cancers by oncogenes and tumor suppressor genes. Science. 2010;330:1340-4.

8. Markert CL. Lactate dehydrogenase isozymes: dissociation and recombination of subunits. Science. 1963;140:1329-30.

9. Koukourakis MI, Giatromanolaki A, Simopoulos C, Polychronidis A, Sivridis E. Lactate dehydrogenase 5 (LDH5) relates to up-regulated hypoxia inducible factor pathway and metastasis in colorectal cancer. Clin Exp Metastasis. 2005;22:25-30.

10. Koukourakis MI, Kontomanolis E, Giatromanolaki A, Sivridis E, Liberis V. Serum and tissue LDH levels in patients with breast/gynaecological cancer and benign diseases. Gynecol Obstet Invest. 2009;67:162-8.

11. Balinsky D, Platz CE, Lewis JW. Isozyme patterns of normal, benign, and malignant human breast tissues. Cancer Res. 1983;43:5895-901.

12. Rong $Y$, Wu W, Ni X, Kuang T, Jin D, Wang D, et al. Lactate dehydrogenase $A$ is overexpressed in pancreatic cancer and promotes the growth of pancreatic cancer cells. Tumor Biol. 2013;34(3):1523-30.

13. Dennison JB, Molina JR, Mitra S, Gonzalez-Angulo AM, Balko JM, Kuba MJ, et al. Lactate dehydrogenase B: a metabolic marker of response to neoadjuvant chemotherapy in breast cancer. Clin Cancer Res. 2013;19:3703-13.

14. Shahriari A, Dawson NJ, Bell RAV, Storey KB. Stable suppression of lactate dehydrogenase activityduring anoxia in the foot muscle of littorinalittorea andthe potential role of acetylation as a novel posttranslationalregulatory mechanism. Enzyme Res. 2013;2013:461374.

15. Brooks SPJA. Simple computer program with statistical tests for the analysis of enzyme kinetics. Biotechniques. 1992;13:906-11.

16. Brooks SPJA. Program for analyzing enzyme rate data obtained from a microplate reader. Biotechniques. 1994;17:1155-61.

17. DeBeradinis RJ. Is cancer a disease of abnormal cellular metabolism? New angles on an old idea. Genet Med. 2008;10:767-77.

18. Dang Chi V. Links between metabolism and cancer. Genes Dev. 2012;26:877-90.

19. De Bari L, Chieppa G, Marra E, Passarella S. L-lactate metabolism can occur in normal and cancer prostate cells via the novel mitochondrial L-lactate dehydrogenase. Int J of Oncol. 2010;37:1607-20.

20. Pizzuto R, Paventi G, Porcile C, Sarnataro D, Daniele A, Passarella S. L-Lactate metabolism in HEP G2 cell mitochondria due to the L-lactate dehydrogenase determines the occurrence of the lactate/pyruvate shuttle and the appearance of oxaloacetate, malate and citrate outside mitochondria. Biochim Biophys Acta. 2010;1817:1679-90.

21. Fukuruma DK, Jain R. Tumor microenvironment abnormalities: causes, consequences, and strategies to normalize. J Cell Biochem. 2007;101:937-49.

22. Markert CL. Lactate dehydrogenase, biochemistry and function of lactate dehydrogenase. Cell Biochem Function. 1984;2:131-4.

23. Brown JM, Giaccia AJ. The unique physiology of solid tumors: Opportunities (and problems) for cancer therapy. Cancer Res. 1998;58:1408-16.

24. Harris AL. Hypoxia: a key regulatory factor in tumour growth. Nat Rev Cancer. 2002;2:38-47.

25. Wigfield SM, Winter SC, Giatromanolaki A, Taylor J, Koukourakis ML, Harris AL. PDK-1 regulates lactate production in hypoxia and is associated with poor prognosis in head and neck squamous cancer. Br J Cancer. 2008;98:1975-84.

26. Thangaraju M, Carswell KN, Prasad PD, Ganapathy V. Colon cancer cells maintain low levels of pyruvate to avoid cell death caused by inhibition of HDAC1/HDAC3. Biochem J. 2009;417:379-89. 
27. Cairns RA, Harris IS, Mak TW. Regulation of cancer cell metabolism. Nat Rev Cancer. 2011;11:85-95

28. Hirschhaeuser F, Salter UGA, Mueller-Klieser W. Lactate: a metabolic key player in cancer. Cancer Res. 2011;71:6921-5.

29. Beckert S, Farrahi F, Aslam RS, Scheuenstuhl H, Konigsrainer A,

ZamirulHussain $\mathrm{M}$, et al. Lactate stimulates endothelial cell migration. Wound Repair Regen. 2006;14:321-4.

30. Walenta S, Mueller-Klieser WF. Lactate: mirror and motor of tumor malignancy. Semin Radiat Oncol. 2004;14(3):267-74.

31. Brizel DM, Schroeder T, Scher RL, Walenta S, Clough RW, Dewhirst MW, et al. Elevated tumor lactate concentrations predict for an increased risk of metastases in head-and-neck cancer. Int J Radiat Oncol Biol Physics. 2001;51(2):349-53.

32. Walenta S, Wetterling M, Lehrke M, Schwickert G, Sundfor K, Rofstad EK, et al. High lactate levels predict likelihood of metastases, tumor recurrence, and restricted patient survival in human cervical cancers. Cancer Res. 2000;60:916-21.

33. Bell RAV, Storey KB. Regulation of liver glutamate dehydrogenase by reversible phosphorylation in a hibernating mammal. Comp Biochem Physiol, Part B. 2010;157:310-6.

34. Porporato PE, Dhup S, Dadhich RK, Copetti T, Sonveaux P. Anticancer targets in the glycolytic metabolism of tumors: a comprehensive review. Frontiers Pharmacol. 2011;2(49):1-18.

\section{Submit your next manuscript to BioMed Central and take full advantage of:}

- Convenient online submission

- Thorough peer review

- No space constraints or color figure charges

- Immediate publication on acceptance

- Inclusion in PubMed, CAS, Scopus and Google Scholar

- Research which is freely available for redistribution 